\title{
AKTIVITAS ANTIOKSIDAN DAN ANTIBAKTERI MINYAK ATSIRI KEMBANG LESON
}

\section{ANTIOXIDANT AND ANTIBACTERIAL ACTIVITY OF KEMBANG LESON ESSENSIAL OIL}

\author{
Ambar Pratiwi*, Inas Salimah \\ Universitas Ahmad Dahlan, Jl. Ringroad Selatan, Tamanan, Bantul, Yogyakarta \\ *Corresponding author: ambar@bio.uad.ac.id
}

Naskah Diterima: 30 Oktober 2018; Direvisi: 20 September 2019; Disetujui: 8 Agustus 2020

\begin{abstract}
Abstrak
Kembang leson adalah racikan jamu untuk mandi yang terdiri dari berbagai obat-obatan herbal yang umum ditemukan di Jawa. Kembang leson mengandung minyak atsiri utama, yaitu camphene $1,29 \%$, benzene methyl cymene 4,93\%, camphor 4,75\%, cyclohexane methanol 7,56\%, dan curdione 4,83\%. Golongan senyawa minyak atsiri dapat menghambat radikal bebas 2,2-diphenyl-1picrylhydrazyl (DPPH) dan memiliki aktivitas antibakteri yang ditunjukkan dengan uji aktivitas antibakteri terhadap Staphylococcus aureus dan Escherichia coli. Tujuan penelitian ini adalah untuk mengetahui aktivitas antioksidan dan antibakteri dari minyak atsiri kembang leson. Minyak Atsiri kembang leson diekstraksi dengan metode destilasi. Minyak atsiri yang diperoleh diuji aktivitas antioksidan dengan metode DPPH, serta aktivitas antibakteri dengan metode difusi. Hasil penelitian menunjukkan bahwa minyak atsiri kembang leson memiliki aktivitas antioksidan dengan persentase penghambatan DPPH sebesar 56,16\%, dan memiliki nilai $\mathrm{IC}_{50}$ (half maximal inhibitory concentration) sebesar $825,78 \mathrm{ppm}$. Aktivitas antibakteri minyak atsiri kembang leson juga efektif menghambat pertumbuhan E. coli, tetapi belum mampu menghambat pertumbuhan $S$. aureus. Minyak atsiri kembang leson dapat digunakan sebagai sumber antioksidan alami.

Kata kunci: Antibakteri; Antioksidan; Kembang leson; Minyak atsiri

Abstract

Kembang leson is an herbal concoction used for bathing. It comprises various herbal medicines found in Java, which contains essential oils such as $1.29 \%$ camphene, $4.93 \%$ benzene methyl cymene, $4.75 \%$ camphor, $7.56 \%$ cyclohexane methanol, and $4.83 \%$ curdione. It is known that essential oils can reduce $D P P H$ free radicals and have antibacterial activity against $S$. aureus and E. coli. Our research is to determine the antioxidant and antibacterial activity of kembang leson essential oil. The essential oil was extracted by distillation. The essential oil obtained was examined for antioxidant activity using the DPPH method and antibacterial activity using the diffusion method. The results showed that kembang leson essential oils have antioxidant and antibacterial activity. The percentage of DPPH inhibition was 56.16\%, and the IC50 value was 825.78 ppm. Antibacterial activity of kembang leson essential oil inhibited E. coli but could not inhibit the growth of $S$. aureus. Thus, kembang leson essential oils have antioxidant and antibacterial activity against $E$. coli, but only have antioxidant activity against $S$. aureus. Further studies are needed to determine the main ingredients that play an important role in the antioxidant mechanism and antibacterial of kembang leson essential oil.
\end{abstract}

Keywords: Antioxidant; Antibacterial; Essential oil; Kembang leson

Permalink/DOI: http://dx.doi.org/10.15408/kauniyah.v13i2.9966 


\section{PENDAHULUAN}

Kembang leson adalah racikan jamu untuk mandi. Racikan tersebut terdiri dari berbagai obat-obatan herbal yang dapat diperoleh di Pulau Jawa berupa aneka rempahrempah, seperti kunyit, jahe, cengkih, jintan, pala, aneka dedaunan, aneka bunga, dan lain sebagainya. Ramuan tersebut dipercaya dapat menghilangkan rasa lesu (leson, Jawa $=$ lesu) yang dialami oleh para pasien yang berada pada masa pemulihan. Kembang leson merupakan ramuan dari beraneka bunga, rimpang, dan daun yang berperan dalam aromatherapy, terutama untuk terapi setelah sakit. Hasil identifikasi komponen dalam ramuan kembang leson menunjukkan bahwa di dalam kembang leson terdapat 18 macam bahan nabati yang umum dimanfaatkan dalam pengobatan tradisional. Komposisi kembang leson adalah batang serai (Cymbopogon nardus), daun pandan wangi (Pandanus amaryllifolium), daun kelapa (Cocos nucifera), daun jeruk purut (Citrus hystrix), daun salam (Syzygium polyanthum), irisan batang secang (Caesalpinia sappan), rasuk angin (Usnea barbata), biji adas (Foeniculum vulgare), pulosari (Alyxia stellata), bunga mawar (Rosa sp.), bunga kenanga (Canangium odoratum), bunga kantil (Michelia champaca), bunga melati (Jasminum sambac), rimpang temulawak (Curcuma xanthorrhizae), rimpang temugiring ( $C$. heyneanae), rimpang temuireng (C. aeruginosa), rimpang dlingo (Acorus calamus), dan rimpang bangle (Zingiber montanum) (Pratiwi, 2018).

Profil kromatografi gas minyak atsiri kembang leson menunjukkan adanya 50 komponen minyak atsiri penyusun. Lima kompenen minyak atsiri yang memiliki luas area tertinggi, yaitu camphene konsentrasinya sebanyak 1,29\%, benzene metil cymene $4,93 \%$, camphor $4,75 \%$, cyclohexane methanol $7,56 \%$ dan curdione 4,83\% (Pratiwi, 2018). Aktivitas biologis minyak atsiri kembang leson belum dikaji terutama aktivitas antioksidannya. Hasil dari beberapa penelitian membuktikan bahwa minyak atsiri memiliki aktivitas antioksidan.

Minyak atsiri pada daun sirih (Piper betle) dapat meredam radikal bebas 2,2-difenil1-pikrilhidrasil (DPPH) sebesar 81,91\%, dibuktikan melalui uji aktivitas peredaman radikal bebas secara UV-Tampak (Parwata,
Rita, \& Yoga, 2009). Minyak bunga cengkih sebanyak $55 \mu \mathrm{L}$ efektif memerangkap radikal bebas alkil hingga $60 \%$, hidroksil $48,57 \%$, dan peroksil $35,71 \%$. Berdasarkan penelitian, komponen aktif dalam minyak cengkih yang memiliki aktivitas antioksidan adalah eugenol (Nurjannah, Retnowati, \& Juswono, 2013).

Penelitian aktivitas antioksidan pada beberapa komponen penyusun kembang leson telah dilakukan. Menurut Putri dan Nisa (2015), ekstrak bunga mawar merah sortiran memiliki rerata aktivitas antioksidan berkisar antara 50,91-79,22\%. Pengujian antioksidan minyak kenanga dengan metode penghambatan radikal bebas DPPH menunjukkan aktivitas antioksidan dengan nilai $\mathrm{IC}_{50} 2,29 \mathrm{mg} / \mathrm{mL}$ (Pujiarti, Widowati, Kasmudjo, \& Sunarta, 2015). Keaktifan dari golongan senyawasenyawa yang berfungsi sebagai antiradikal bebas ditentukan adanya gugus fungsi $-\mathrm{OH}$ (hidroksil) bebas dan ikatan rangkap karbonkarbon, seperti flavon, flavanon, skualen, tokoferol, karoten, vitamin $\mathrm{C}$, dan lain-lain (Rahmawati, 2004; Parwata, 2016).

Selain memiliki aktivitas antioksidan, minyak atsiri memiliki aktivitas antibakteri, ditunjukkan dengan uji aktivitas antibakteri. Minyak atsiri daun pala diketahui memiliki 33 komponen kimia, dengan 5 komponen kimia terbesarnya, yaitu sabinene, terpinene-4-ol, $\alpha$ pinene, $\beta$-pinene, dan $\beta$-phellandrene. Minyak atsiri daun pala dengan konsentrasi 3,125\% memiliki aktivitas antibakteri terhadap $S$. aureus dengan zona hambat sebesar 16,81 mm dan konsentrasi minyak atsiri $1 \%$ mampu menghambat $E$. coli dengan zona hambat sebesar 0,54 $\mathrm{mm}$ (Rastuti, Widyaningsih, Kartika, \& Ningsih, 2013). Nilai konsentrasi bunuh minimal minyak atsiri daun kemangi terhadap $S$. aureus adalah $0,5 \%$, sedangkan nilai konsentrasi bunuh minimumnya terhadap E. coli sebesar $0,25 \%$ (Maryati, Fauzia, \& Rahayu, 2007). Demikian pula hasil penelitian Mardiyaningsih dan Aini (2014), ekstrak etil asetat daun pandan menunjukkan potensi penghambatan yang paling tinggi, dengan nilai konsentrasi hambat minimum dan konsentrasi bunuh minimum $1,1 \% \mathrm{~b} / \mathrm{v}$ dan $6,7 \% \mathrm{~b} / \mathrm{v}$ terhadap $S$. aureus serta $0,5 \% \mathrm{~b} / \mathrm{v}$ dan $4,5 \% \mathrm{~b} / \mathrm{v}$ terhadap E. coli. Konsentrasi ekstrak temulawak 500 ppm efektif sebagai antibakteri terhadap $E$. coli dengan diameter zona hambat 
sebesar 10,37 mm dan $S$. aureus sebesar 8,44 mm (Purnamaningsih, Kalor, \& Atun, 2017). Mekanisme antibakteri minyak atsiri kemungkinan terjadi, karena pengikatan senyawa fenol dengan sel bakteri, sehingga mengganggu permeabilitas membran dan proses transportasi. Hal tersebut mengakibatkan hilangnya kation dan makromolekul sel, menyebabkan terganggunya pertumbuhan sel, atau kematian. Pada konsentrasi rendah, senyawa fenol akan menyebabkan denaturasi protein dan pada konsentrasi tinggi akan menyebabkan koagulasi protein sehingga sel akan mati (Siswandono, 1995).

Tanaman yang menjadi komposisi kembang leson melimpah keberadaannya, sehingga lebih mudah untuk dikaji, dan penelitian yang telah ada lebih menekankan kandungan dari setiap tanaman dan aktivitas biologisnya. Penelitian ini perlu dilakukan, karena belum ada penelitian tentang aktivitas antioksidan dan antibakteri dari minyak atsiri kembang leson. Hasil penelitian ini dapat digunakan sebagai pijakan untuk pegembangan pemanfaatan minyak atsiri kembang leson sebagai produk fitofarmaka.

\section{MATERIAL DAN METODE}

Bahan yang digunakan dalam penelitian adalah kembang leson yang diperoleh dari Pasar Gamping, Sleman, biakan E. coli dan $S$. aureus dari Laboratorium Biologi FMIPA Universitas Ahmad Dahlan Yogyakarta.

\section{Isolasi Minyak Atsiri Kembang Leson}

Sebanyak 5,150 g racikan kembang leson segar dibersihkan dan dipotong kecil-kecil, kemudian dimasukkan ke dalam alat destilasi uap air, dan dididihkan selama 8-12 jam. Destilat yang diperoleh merupakan minyak atsiri yang kemudian ditempatkan dalam botol tertutup dan disimpan di dalam lemari pendingin.

\section{Uji Aktivitas Antioksidan}

Uji aktivitas antioksidan menggunakan DPPH sebagai radikal bebas. Asam galat digunakan sebagai larutan pembanding aktivitas antioksidan. Larutan stok asam galat konsentrasi $100 \mathrm{ppm}$ dibuat dengan melarutkan $10 \mathrm{mg}$ asam galat dengan pelarut metanol p.a (pro analys) dalam labu takar ukuran $100 \mathrm{~mL}$. Dari larutan stok asam galat 100 ppm dibuat larutan asam galat dengan variasi konsentrasi $80 ; 60 ; 40$; dan 20 ppm. Variasi konsentrasi tersebut dibuat dengan memasukkan sebanyak 4; 3; 2; dan $1 \mathrm{~mL}$ larutan stok ke dalam tabung reaksi dan ditambahkan metanol p.a hingga batas volume $5 \mathrm{~mL}$. Larutan stok minyak atsiri kembang leson konsentrasi 1.000 ppm dibuat dengan melarutkan $0,1 \mathrm{~mL}$ minyak atsiri dan pelarut metanol p.a dalam labu takar berukuran $100 \mathrm{~mL}$. Larutan stok 1.000 ppm kemudian dibuat larutan dengan variasi konsentrasi 800; 600; 400; dan 200 ppm. Variasi konsentrasi tersebut dibuat dengan cara melarutkan $4 ; 3 ; 2$; dan $1 \mathrm{~mL}$ larutan stok dalam tabung reaksi dengan penambahan metanol p.a sampai batas volume $5 \mathrm{~mL}$.

Pengukuran absorbansi untuk penentuan persentase penghambatan dilakukan pada blanko, larutan asam galat, dan larutan minyak atsiri yang telah dibuat dengan berbagai variasi konsentrasi. Untuk pembuatan larutan blanko, sebanyak $2 \mathrm{~mL}$ larutan DPPH $0,3 \mathrm{mM}$ ditambahkan dengan $1,2 \mathrm{~mL}$ metanol p.a, dalam tabung reaksi, dihomogenkan menggunakan vortex dan diinkubasi selama 30 menit dalam kondisi gelap. Untuk pengukuran absorbansi larutan pembanding, sebanyak 2 $\mathrm{mL}$ larutan DPPH $0,3 \mathrm{mM}$ ditambahkan dengan 1,2 $\mathrm{mL}$ asam galat, dihomogenkan menggunakan vortex, dan diinkubasi selama 30 menit dalam kondisi gelap. Sebanyak $2 \mathrm{~mL}$ larutan DPPH 0,3 mM ditambahkan 1,2 mL minyak atsiri kembang leson, dihomogenkan menggunakan vortex dan diinkubasi selama 30 menit dalam kondisi gelap. Nilai absorbansi diukur menggunakan spektrofotometer dengan panjang gelombang maksimum $517 \mathrm{nM}$.

Setelah diketahui nilai absorbansi dari larutan blanko dan sampel, dipenghitung persentase penghambatan dengan rumus: \% penghambatan $=$ (absorbansi blanko absorbansi sampel)/absorbansi blanko x $100 \%$. Untuk memperoleh nilai $\mathrm{IC}_{50}$ aktivitas antioksidan asam galat dan minyak atsiri kembang leson, dibuat kurva persamaan linear yang menghubungkan antara konsentrasi bahan dengan persentase penghambatan. Dari kurva linear diperoleh persamaan linier $y=a x+b$ untuk asam galat maupun minyak atsiri kembang leson. Berdasarkan persamaan $\mathrm{y}=\mathrm{ax}$ + b dapat ditentukan nilai-nilai $\mathrm{IC}_{50}$. Nilai $\mathrm{IC}_{50}$ adalah konsentrasi yang menyebabkan adanya 
penurunan 50\% dari konsentrasi DPPH awal (Sunarni, 2005).

\section{Uji Aktivitas Antibakteri}

Media nutrient agar (NA) disiapkan dalam cawan petri. Biakan E. coli dan $S$. aureus diinokulasikan dengan cara spread dan diinkubasi selama 12 jam pada suhu $37{ }^{\circ} \mathrm{C}$. Setelah itu, sebanyak $0,1 \mathrm{~mL}$ minyak atsiri diambil menggunakan metode swab dan diratakan di atas permukaan biakan bakteri, diinkubasi kembali selama 24 jam pada suhu $37{ }^{\circ} \mathrm{C}$. Setelah 24 jam, biakan diamati ada atau tidaknya penghambatan pertumbuhan bakteri oleh minyak atsiri.
HASIL

Aktivitas Antioksidan Minyak Atsiri Kembang Leson

Pengukuran aktivitas antioksidan dilakukan untuk mengetahui potensi penghambatan radikal bebas oleh minyak atsiri kembang leson. Aktivitas antioksidan dapat ditentukan dari nilai persentase penghambatan terhadap DPPH, kemudian dapat ditentukan nilai $\mathrm{IC}_{50}$ untuk mengetahui seberapa besar konsentrasi minyak atsiri kembang leson secara efektif menghambat radikal DPPH (Tabel 1).

Tabel 1. Persentase penghambatan radikal DPPH oleh minyak atsiri kembang leson

\begin{tabular}{cccc}
\hline $\begin{array}{c}\text { Asam galat } \\
\text { Konsentrasi (ppm) }\end{array}$ & \%Hambat & \multicolumn{2}{c}{ Minyak atsiri kembang leson } \\
Konsentrasi $(\mathrm{ppm})$ & 20,09 \\
\hline 20 & 58,58 & 200 & 27,66 \\
40 & 63,62 & 400 & 43,50 \\
60 & 74,73 & 600 & 49,50 \\
80 & 88,91 & 800 & 56,16 \\
100 & 89,23 & 1000 & \\
\hline
\end{tabular}
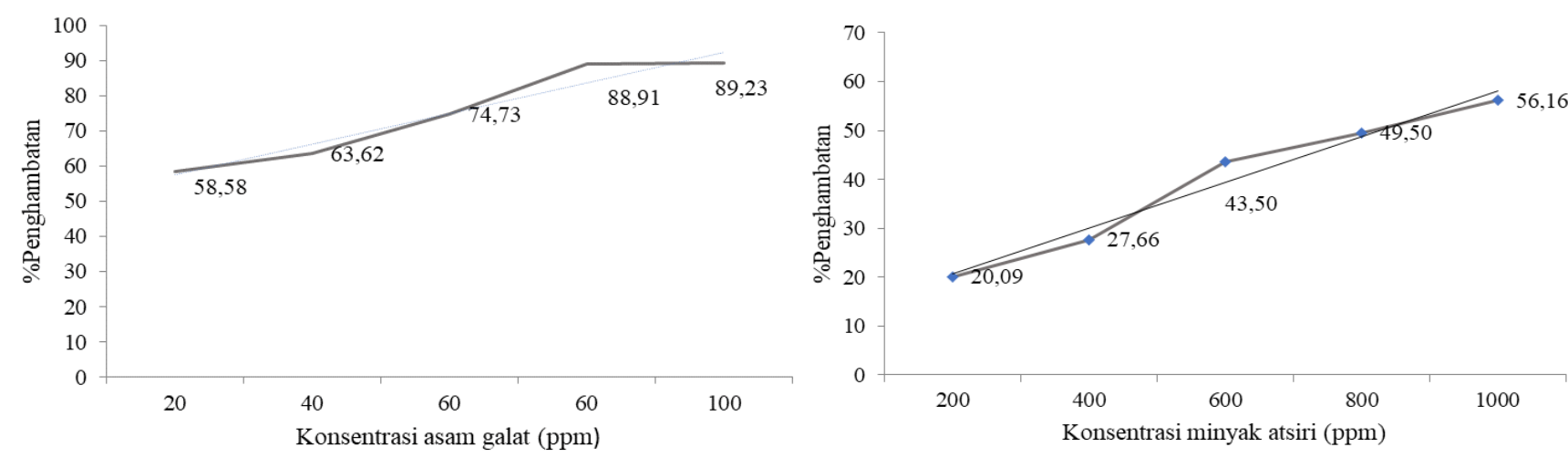

Gambar 1. Kurva aktivitas: antioksidan asam galat (a) dan antioksidan minyak atsiri kembang leson (b)

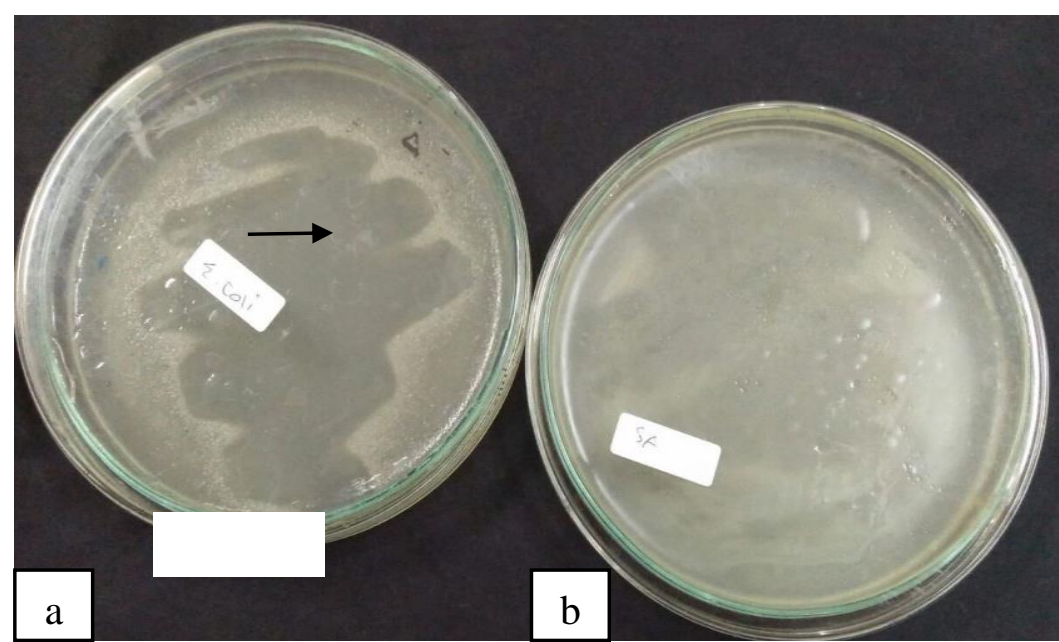

Gambar 2. Aktivitas antibakteri minyak atsiri kembang leson pada Escherichia coli (a) dan Staphylococcus aureus (b). Tanda panah menunjukkan zona hambat 


\section{Aktivitas Antibakteri Minyak Atsiri Kembang Leson}

Berdasarkan hasil uji antibakteri, minyak atsiri kembang leson dapat menghambat pertumbuhan $E$. coli dengan terbentuknya zona bening (Gambar 1a), sementara S. aureus tidak mengalami hambatan pertumbuhan dengan adanya minyak atsiri kembang leson. Hasil yang berbeda ini dapat dikaitkan dengan sifat kedua bakteri tersebut.

\section{PEMBAHASAN}

\section{Aktivitas Antioksidan Minyak Atsiri Kembang Leson}

Pengujian aktivitas antioksidan minyak atsiri kembang leson dilakukan dengan metode DPPH. Metode DPPH adalah salah satu metode pengukuran aktivitas antioksidan dalam menghambat radikal bebas melalui hydrogen atom transfer, yaitu dengan cara mendonorkan atom $\mathrm{H}$ untuk menetralkan radikal bebas, dalam hal ini DPPH (Apak, Kubilay, Mustafa, \& Saliha, 2007). Uji aktivitas antioksidan dengan metode DPPH menggunakan prinsip kerja adanya penghambatan radikal bebas DPPH. Hal ini ditunjukkan dengan penurunan nilai absorbansi pada panjang gelombang maksimum, penurunan absorbansi terjadi karena pengurangan radikal oleh antioksidan. Nilai absorbansi yang rendah disebabkan radikal DPPH dihambat oleh senyawa antioksidan melalui proses donor atom hidrogen. Proses donor atom hidrogen oleh antioksidan bertujuan membentuk radikal yang stabil, ditunjukkan dengan perubahan warna ungu menjadi warna kuning (Gulcin, 2006). Secara kualitatif, banyaknya atom hidrogen yang didonorkan oleh senyawa aktif dapat diketahui dengan terjadinya perubahan warna larutan DPPH dari ungu menjadi kuning.

Persentase penghambatan radikal DPPH semakin meningkat seiring dengan peningkatan konsentrasi asam galat dan minyak atsiri (Tabel 1). Hal ini karena pada konsentrasi yang lebih tinggi terdapat senyawa aktif yang lebih banyak sehingga lebih efektif dalam menangkal radikal DPPH. Persentase penghambatan pada asam galat lebih besar dibandingkan persentase penghambatan pada minyak atsiri kembang leson. Asam galat merupakan asam heteropoli yang mempunyai 3 gugus hidroksi fenolat (Pior, Wu, \& Schaich, 2005). Asam galat digunakan sebagai senyawa pembanding, karena merupakan salah satu asam fenolik yang banyak terdapat pada tanaman (Fiuza, 2004). Asam galat merupakan senyawa fenolik dan diketahui sebagai antioksidan yang kuat (Nurwaini, Sofiana, Noor, \& Rahayu, 2006), sehingga besarnya persentase penghambatan antioksidan pada asam galat disebabkan oleh banyaknya atom hidrogen yang diberikan senyawa fenolik kepada radikal DPPH.

Persentase penghambatan dan nilai $\mathrm{IC}_{50}$ pada minyak atsiri kembang leson lebih kecil dari asam galat. Nilai $\mathrm{IC}_{50}$ dari asam galat dan minyak atsiri kembang leson, masing-masing adalah 2,22 ppm dan 825,78 ppm (Gambar 1). Suatu senyawa dikatakan sebagai antioksidan sangat kuat jika nilai $\mathrm{IC}_{50}$ kurang dari 50, kuat (50-100), sedang (100-150), dan lemah (151200). Semakin kecil nilai $\mathrm{IC}_{50}$ semakin tinggi aktivitas antioksidan (Badarinath et al., 2010). Berdasarkan hasil penelitian dan merujuk Badarinath et al. (2010), maka dikatakan minyak atsiri kembang leson termasuk senyawa antioksidan yang lemah.

Minyak atsiri kembang leson memiliki aktivitas antioksidan yang rendah dapat karena minyak atsiri tersusun dari senyawa yang heterogen dan juga dipengaruhi oleh senyawasenyawa lain yang terkandung dalam minyak atsiri kembang leson. Minyak atsiri kembang leson terdiri dari racikan yang terdiri dari berbagai macam bunga, rimpang, dan dedaunan, tidak seperti senyawa penyusun asam galat. Tingkat heterogen tersebut memungkinkan adanya senyawa-senyawa yang tidak memiliki aktivitas antioksidan atau menghambat reaksi antioksidan. Berdasarkan penelitian Pujiarti et al. (2015), aktivitas antioksidan yang lebih rendah pada minyak kenanga kemungkinan disebabkan adanya kandungan senyawa seskuiterpen hidrokarbon seperti caryophyllene dan seskuiterpen teroksigenasi seperti linalool yang berpotensi sebagai pro-oksidan.

Aktivitas antioksidan minyak atsiri kembang leson lebih rendah dari aktivitas antioksidan asam galat dapat karena sedikitnya jumlah kandungan senyawa dalam minyak atsiri kembang leson yang berpotensi sebagai antioksidan. Berdasarkan kromatografi gas, 
beberapa penyusun minyak atsiri kembang leson antara lain camphene, benzene methyl cymene, camphor, cyclohexane methanol, curdione, benzene 1-(1.5-dimethyl-4-hexenyl)4-methyl-(CAS) ar Curcumene, $\alpha$-pinene, dan camphene (Pratiwi, 2018). Curcumene merupakan komponen utama yang berpengaruh terhadap aktivitas antioksidan pada temulawak (Kikuzaki, 2000), sehingga diketahui bahwa senyawa benzene 1-(1.5dimethyl-4-hexenyl)-4-methyl-(CAS)

Curcumene yang terkandung dalam komponen penyusun minyak atsiri kembang leson berpotensi sebagai antioksidan.

Penelitian lain mengatakan bahwa pada ekstrak air kayu manis telah diketahui memiliki beberapa jenis komponen terpenoid termasuk $\alpha$-pinene dan camphene. Komponen aktif ini memiliki potensi antioksidan dan dapat mencegah atau mengurangi kerusakan oksidatif sel (Roussel, Hininger, Benabara, Ziengenfuss, \& Anderson, 2009), sehingga diketahui bahwa $\alpha$-pinene dan camphene (CAS) pada komponen penyusun minyak atsiri kembang leson berpotensi sebagai antioksidan. Keaktifan dari golongan senyawasenyawa yang berfungsi sebagai antiradikal bebas ditentukan adanya gugus fungsi $-\mathrm{OH}$ (hidroksil) bebas dan ikatan rangkap karbonkarbon, seperti flavon, flavanon, skualen, tokoferol, karoten, vitamin $\mathrm{C}$, dan lain-lain (Rahmawati, 2004; Parwata, 2016).

\section{Aktivitas Antibakteri Minyak Atsiri Kembang Leson}

Berdasarkan hasil uji antibakteri, minyak atsiri kembang leson dapat menghambat pertumbuhan E. coli (Gambar 1a). Hal tersebut disebabkan E. coli (gram negatif) memiliki dinding sel dengan komponen utama lapisan lipopolisakarida, lipid, dan lipoprotein (Pratiwi, 2008). Bakteri gram negatif memiliki dinding sel peptidoglikan hanya sekitar $10 \%$ dari masa kering dinding sel, sehingga menyebabkan dinding selnya lebih tipis (Putri, Putra, \& Utama, 2018).

Minyak atsiri kembang leson tidak mampu menghambat pertumbuhan S. aureus, karena dipengaruhi oleh struktur dinding sel bakteri. S. aureus (gram positif) yang memiliki lapisan peptidoglikan tebal dan asam teikoat. Dinding sel bakteri gram positif terdiri atas sekitar 40 lapisan peptidoglikan sehingga menyebabkan dinding sel menjadi tebal dan kaku (Putri et al., 2018).

Keberadaan lapisan lipid dan tipisnya dinding sel bakteri $E$. coli dibandingkan dengan $S$. aureus, memungkinkan lebih mudah ditembus oleh senyawa-senyawa yang relatif nonpolar seperti minyak atsiri kembang leson ini. Sehingga minyak atsiri kembang leson lebih efektif menghambat $E$. coli dibandingkan dengan $S$. aureus. Profil kromatografi gas minyak atsiri kembang leson menunjukkan adanya 50 komponen penyusun di antaranya ada lima kompenen minyak atsiri yang memiliki luas area tertinggi yaitu benzene metyl cymene 4,93\%, camphor $4,75 \%$, cyclohexane methanol $7,56 \%$ dan curdione 4,83\% (Pratiwi, 2018). Berdasarkan struktur kimianya, benzene methyl cymene dan cyclohexane methanol termasuk dalam golongan minyak atsiri dengan gugus hidroksil (golongan fenolik). Tiga senyawa minyak atsiri utama kembang leson termasuk dalam terpen.

Mekanisme aksi terpen sebagai antibakteri, karena kemampuan terpen (senyawa lipofilik) dalam menyebabkan gangguan membran (Cowan, 2009).Terpenoid dapat bereaksi dengan porin (protein transmembran) pada membran luar dinding sel bakteri, membentuk ikatan polimer yang kuat dan merusak porin, mengurangi permeabilitas dinding sel bakteri sehingga sel bakteri kekurangan nutrisi, pertumbuhan bakteri terhambat atau mati (Rachmawati, Nuria, \& Sumantri, 2011).

Mekanisme antibakteri juga disebabkan pengikatan senyawa fenol dengan sel bakteri, kemudian akan mengganggu permeabilitas membran dan proses transportasi. Hal tersebut mengakibatkan hilangnya kation dan makromolekul dari sel, sehingga pertumbuhan sel akan terganggu atau mati. Pada konsentrasi rendah, senyawa fenol akan menyebabkan denaturasi protein dan pada konsentrasi tinggi akan menyebabkan koagulasi protein sehingga sel akan mati (Siswandono, 1995). Hal tersebut diperkuat oleh Ali, Baharuddin, dan Sappewali (2013) yang menyatakan bahwa mekanisme antibakteri dari golongan fenolik adalah dengan mendenaturasi protein, karena fenol merusak membran sel dengan cara melarutkan lipid. 


\section{SIMPULAN DAN SARAN}

Minyak atsiri kembang leson memiliki aktivitas antioksidan dengan nilai penghambatan DPPH sebesar 56,16\% dan nilai $\mathrm{IC}_{50}$ sebesar $825,78 \mathrm{ppm}$. Minyak atsiri kembang leson memiliki aktivitas antibakteri, karena mampu menghambat pertumbuhan $E$. coli. Perlu dilakukan kajian lebih lanjut mengenai kandungan utama minyak atsiri kembang leson yang berperan dalam mekanisme antioksidan dan antibakteri.

\section{REFERENSI}

Ali, S. M., Baharuddin., \& Sappewali. (2013). Pengujian aktivitas antibakteri minyak atsiri jahe (Zingiber officinale Roscoe) terhadap bakteri Staphylococcus aureus dan Escherichia coli. Al Kimia, 1(2), 1831.

Apak, R., Kubilay, G., Mustafa, O., \& Saliha, E. C. (2007). Comparative evaluation of various total antioxidant capacity assays applied to phenolic compounds eith the CUPRAC assay. Molecules, 12(7), 14961547.

Badarinath, A., Rao, K., Chetty, C. S., Ramkanth, S., Rajan, T., \& Gnanaprakash, K. A. (2010). Review on in-vitro antioxidant methods: Comparisons, correlations, and considerations. International Journal of Pharm Tech Research, 2(2), 1276-1285.

Cowan, M. (2009). Plant product as antimicrobial agent. Clinical Microbiology Reviews, 12(4), 564-582.

Fiuza, S. M., Gomes, C., Teixeira. L. J., Da Cruz, G. M. T., Cordeiro, M. N. D. S., \& Milhazes, N. (2004). Phenolic acid derivates with potential anticancer properties a structure activity relationship study part 1: Methyl, prophyl, and octyl esters of caffeic and gallic acids. Bioorganic and Medicall Chemistry, 12(13), 3581-3589.

Gulcin, I. (2006). Antioxidant and antiradical activities of l-carnitine. Life Sciences, 78(8), 803-811.

Kikuzaki, H. (2000). Ginger for drug and spice purpose. In G. Mazza, \& B. D. Oomah (Eds.), Herbs, botanicals and teas (pp. 75-105). Lancaster, USA: Technomic Publishing Company.
Mardiyaningsih, A., \& Aini, R. (2014). Pengembangan potensi ekstrak daun pandan (Pandanus amaryllifolius Roxb) sebagai agen antibakteri. Pharmaçiana, 4(2), 185-192.

Maryati, R. S., Fauzia, T., \& Rahayu. (2007). Uji aktivitas antibakteri minyak atsiri daun kemangi (Ocimum basilicum L.) terhadap Staphylococcus aureus dan Escherichia coli. Jurnal Penelitian Sains \& Teknologi, 8(1), 30-38.

Nurjannah, D. A., Retnowati, R., \& Juswono, U. P. (2013). Aktivitas antioksidan dari minyak bunga cengkeh (Syzygium aromaticum) kering berdasarkan aktivatas antiradikal yang ditentukan menggunakan ESR. Kimia Student Journal, 1(2), 283-288.

Nurwaini, S., Sofiana, Y. R., Noor, I. R., \& Rahayu, R. (2006). Uji aktivitas antiradikal ekstrak herba cakar ayam (Selaginella doederleinii Hieron), herba keladi tikus (Typhonium divaricatum (L) Decne) dan daun Eugenia uniflora Linn sebagai sumber alternatif pencegahan degeneratif (Laporan Program Kreativitas Mahasiswa-Penelitian). Fakultas Farmasi, Universitas Muhammadiyah Surakarta, Surakarta, Indonesia.

Parwata, I. M. O. A. (2016). Bahan ajar: Antioksidan. Bali: Program Pascasarjana Universitas Udayana.

Parwata, I. M. O. A., Rita, W. S, \& Yoga, R. (2009). Isolasi dan uji antiradikal bebas minyak atsiri pada daun sirih (Piper betle Linn) secara spektroskopi ultraviolettampak. Jurnal Kimia, 3(1), 7-13.

Pior, R. L., Wu, X., \& Schaich, K. (2005). Standardized methods for the determination of antioxidant capacity and phenolics in foods and dietary supplements. Journal of Agricultural and Food Chemistry, 53(10), 4290-4302.

Pratiwi, S. T. (2008). Mikrobiologi farmasi. Jakarta: Erlangga.

Pratiwi, A. (2018). Isolasi dan analisis kandungan minyak atsiri pada kembang leson. Bioeksperimen. 4(1), 42-47. 
Pujiarti, R., Widowati, T. B., Kasmudjo., \& Sunarta, S. (2015). Kualitas, komposisi kimia dan aktivitas antioksidan minyak kenanga (Cananga adonata). Jurnal Ilmu Kehutanan, 9(1), 8-10.

Purnamaningsih, N. A., Kalor, H., \& Atun, S. (2017). Uji aktivitas antibakteri ekstrak temulawak (Curcuma xanthorrhiza) terhadap bakteri Escherichia coli ATCC 11229 dan Staphylococcus aureus ATCC 25923. Jurnal Penelitian Saintek, 22(2), 140-147.

Putri, A. R. W., \& Nisa, F. C. (2015). Ekstraksi antosianin bunga mawar merah sortiran metode MAE. Jurnal Pangan dan Agroindustri, 3(2), 701-712.

Putri, Y. W., Putra, A. E., \& Utama, B. I. (2018). Identifikasi dan karakteristik bakteri asam laktat yang diisolasi dari vagina wanita usia subur. Jurnal Kesehatan Andalas, 7(3), 20-25.

Rachmawati, F., Nuria, M. C., \& Sumantri. (2011, December 17). Uji aktivitas antibakteri fraksi kloroform ekstrak etanol pegagan (Centella asiatica (L) Urb) serta identifikasi senyawa aktifnya. Paper presented at the Seminar Nasional "Peranan dan Kontribusi Herbal dalam Terapi Penyakit Degeneratif' Universitas Wahid Hasyim, Semarang, Indonesia. Retrieved https://publikasiilmiah.unwahas.ac.id/ind ex.php/Farmasi/issue/view/30.

Rahmawati, D. (2004). Uji antiradikal bebas senyawa golongan flavonoid pada ekstrak metanol buah mengkudu (Morinda Citrifolia $\quad$ L.) secara spektroskopi (Skripsi sarjana). Jurusan Kimia, FMIPA, Universitas Udayana, Bali, Indonesia.

Rastuti, U., Widyaningsih, S., Kartika, D., \& Ningsih, D. R. (2013). Aktivitas antibakteri minyak atsiri daun pala dari Banyumas terhadap Staphylococcus aureus dan Escherichia coli serta identifikasi senyawa penyusunnya. Molekul, 8(2), 197-203.

Roussel, A. M., Hininger, I., Benabara, R., Ziengenfuss, T. N., \& Anderson, R. A. (2009). Antioxidant effect of a cinnamon extract in people with impaired fasting glucose that are overweight or obese. Journal of the American College of Nutrition, 28(1), 16-21.

Siswandono, S. (1995). Prinsip-prinsip rancangan obat. Surabaya: Airlangga University.

Sunarni, T. (2005). Aktivitas antioksidan penangkap radikal bebas beberapa kecambah dari biji tanaman familia Papilionaceae. Jurnal Farmasi Indonesia, 2(2), 53-61. 